\title{
Modelling of Unreinforced Masonry Infill Panels
}

\author{
[ Trevor Neville Haas, Wesley Jarvis ]
}

\begin{abstract}
Commercial and residential buildings are usually constructed of steel or reinforced concrete frames with unreinforced masonry infill panels. Many codes of practice ignore the stiffness during design process for ease of design. Many designer engineers also do not know how to incorporate this additional stiffness from the unreinforced masonry infill panels into the design process. This leads to an incorrect assessment of the building's robustness when subjected to lateral loading and especially when subjected to seismic ground motion. The natural frequencies, corresponding mode shapes and the strength of the building is therefore incorrectly assessed leading to an overdesign. When these buildings are modelled using Finite Element Analysis, it is imperative that the strength of the unreinforced masonry infill panels are correctly accounted for, to prevent over strengthening the columns to yield the same experimental test results. The paper therefore focuses on describing the possible failure modes caused by unreinforced masonry infill panels on reinforced concrete framed structures and the FE modelling techniques required to obtain a computationally efficient model. The investigation shows the significant effect of the unreinforced masonry infill panels on the robustness of the global model.
\end{abstract}

Keywords - stiffness of unreinforced masonry panels, FE analysis, equivalent strut method

\section{Introduction}

Commercial and residential buildings are usually constructed of either a structural steel frame with masonry infill or a reinforced concrete $(\mathrm{RC})$ frame with masonry infill. The structural steel frame is composed of steel sections used as columns and beams, while the RC frame is constructed of RC columns, beams, slabs with unreinforced masonry infill panels. The choice of the frame depends on the client's requirements as well as the design engineers experience with using either structural steel or RC. It is common practice for design engineers to assume that the unreinforced masonry panels do not add additional stiffness to the frame. This is usually done for ease of design and the limited knowledge

\section{Trevor Neville Haas, Ph.D}

Department of Civil Engineering, Stellenbosch University South Africa

Wesley Jarvis, M. Eng.

Department of Civil Engineering, Stellenbosch University South Africa design engineers have with respect to the additional stiffness provided by the unreinforced masonry panels. When the frame is subjected to lateral loading, the unreinforced masonry significantly enhances the lateral stiffness of the structure [1]. The natural frequency and mode shape responses are thus significantly affected as a result of the additional stiffness from the unreinforced infill masonry panel [2].

It is therefore imperative that the additional stiffness is taken into account when any simulation work is conducted. Failure to account for the additional stiffness will result in a finite element (FE) model with a reduced natural frequency $(\omega)$ and reduced period $(\mathrm{T})$. By ignoring the additional stiffness of the unreinforced masonry infill panels will result in an increased stiffness of the columns when the FE model is calibrated to the experimental test data.

This paper is a result of work conducted to analyse an existing three storey RC framed building with masonry infill subjected to earthquake loading. Since no experimental data on the actual structure exists, it was necessary to calibrate a FE model to a similar building for which experimental test data is available before analysing the actual structure. Therefore, this paper focuses on describing the possible failure modes caused by unreinforced masonry infill panels on $\mathrm{RC}$ framed structures and the FE modelling techniques required to obtain a computationally efficient model. These modelling techniques were used to model the actual structure when subjected to seismic loading. The seismic response of the actual building is however not covered in this paper.

\section{Literature Review}

\section{A. Failure Modes Caused by Masonry Infill Panels on RC Frames}

A $10 \mathrm{~mm}$ to $15 \mathrm{~mm}$ gypsum board is normally placed between the RC frame and the unreinforced masonry panels to ensure that the panels do not rigidly "butt" against the frame during lateral loading. If this occurs, it could lead to plastic hinges developing in the columns. Depending on the masonry failure, it could lead to numerous failure modes in the column [2]. It is important to note that panel failure will not lead to global failure and is therefore not the prime emphasis of this paper. However, the failure of the columns as a result of the masonry panel effect, can lead to local or global failure, which is the focus of this paper.

Different failure modes of the unreinforced masonry panels and the associated formation of plastic hinges in the columns are shown in Fig. 1a to 1d. Table I list the most common failure modes in RC columns caused by masonry infill when subjected to lateral loading. 


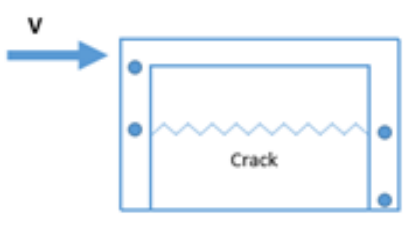

FIGURE 1A

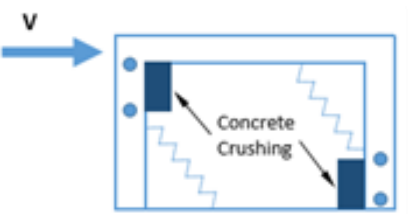

FIGURE 1C

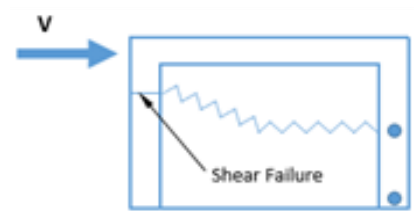

FIGURE 1B

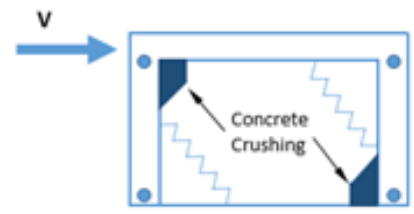

FIGURE 1D

FIGURE 1A TO 1D FAILURE PATTERNS OF UNREINFORCED MASONRY PANELS

TABLE I. CAUSES OF FAILURE

\begin{tabular}{|c|l|}
\hline $\begin{array}{c}\text { Figure } \\
\text { Number }\end{array}$ & \multicolumn{1}{c|}{ Causes of failure } \\
\hline $1 \mathrm{~A}$ & $\begin{array}{l}\text { Caused by weak mortar and strong RC frame leading to } \\
\text { short column effect [3]. }\end{array}$ \\
\hline 1B & $\begin{array}{l}\text { Caused by weak RC frame joints with strong members } \\
\text { and infill leading to brittle shear failure in the columns } \\
\text { [4]. }\end{array}$ \\
\hline $1 \mathrm{C}$ & $\begin{array}{l}\text { Concrete crushing associated with a strong frame with } \\
\text { weak masonry panels [3]. }\end{array}$ \\
\hline $1 \mathrm{D}$ & $\begin{array}{l}\text { Caused by weak joints with respect to the masonry } \\
\text { panels leading to plastic hinges at the joints [3]. }\end{array}$ \\
\hline
\end{tabular}

It is therefore essential that the masonry infill is modelled correctly since it can lead to various failure modes in the column(s) resulting in local and/or global failure when the RC frame is subjected to lateral loading.

\section{B. Modelling of the Masonry Infill}

Various authors investigated and proposed different methods to model masonry infill panels to reduce the computational effort during FE simulations. The methods investigated are; micro model, macro model and the equivalent strut model. The equivalent strut methods is the most computationally efficient of these proposed methods. It was established that the masonry panel behaves similar a strut when laterally loaded [1], [5], [6]. The authors however disagreed on the dimensions of the length and width of the strut. The formulae presented by these authors to determine the geometric and material properties of the strut did not account for any openings in the masonry panels.

The proposed methods did not accurately capture the lateral stiffness as well as the shear force and bending moments in the columns. Various modified equivalent strut models proposed by other researchers to accurately capture the lateral stiffness, shear force and bending moments in the columns are presented in Fig. $2 \mathrm{a}$ to 2 d. The models in Fig. $2 \mathrm{a}$ to $2 \mathrm{c}$ had some limitations in that it was not able to accurately predict the three mentioned criteria. However, the model shown in Fig. 2d can capture the local as well as global failure mechanisms of the column when subjected to lateral loading [7]. This model is also computationally efficient compared to the other methods.

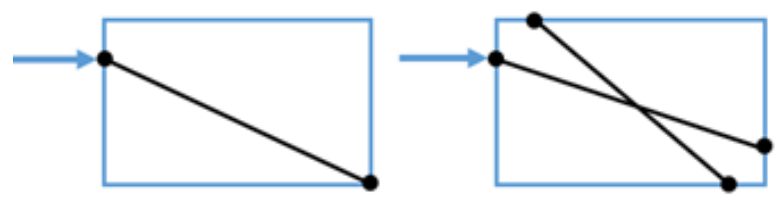

FIGURE 2A

FIGURE 2B

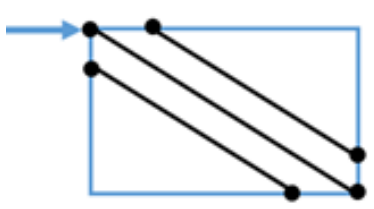

FIGURE 2C

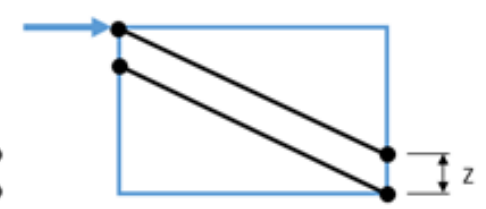

FIGURE 2D

\section{Figure 2A To 2D Proposed EQUivalent STRUT MODELS}

Using a combination of various researchers work, the equivalent properties of the unreinforced masonry panel, i.e. the strut, was agreed to as:

The width, $w$, of the strut proposed by Paulay and Priestley is given in (1) as, [1];

$$
w=0.25 d_{m}
$$

where; $w$ and $d_{m}$ are defined in Fig. 3.

Stafford-Smith determined a parameter, $\lambda_{\mathrm{h}}$, which relates the stiffness of the frame to the masonry given in (2) as, [8];

$$
\lambda_{h}=h^{4} \sqrt{\frac{E_{m} t \sin 2 \theta}{4 E_{c} I_{c} h_{m}}}
$$

where;

$E_{m}$ is the Modulus of Elasticity of the masonry

$E_{C}$ is the Modulus of Elasticity of the concrete

$I_{C}$ is the second moment of inertia of the concrete

$t$ is the wall thickness

where; $h, h_{m}$ and $\theta$ are defined in Fig. 3.

Mainstone, and Liauw and Kwan proposed revised equivalent strut widths after the work conducted by Stafford-Smith given in (3) and (4) as, [9] and [10];

$$
\begin{aligned}
& w=0.16 \lambda_{h}-0.3 d_{m} \\
& w=\frac{0.95 h_{m} \cos \theta}{\sqrt{\lambda_{h}}}
\end{aligned}
$$

A reduction factor, $\mathrm{R}$, to reduce the width of the strut to account for door and window openings is given in (5) as, [11]

$R=0.6\left(\frac{A_{\text {open }}}{A_{\text {panel }}}\right)^{2}-1.6\left(\frac{A_{\text {open }}}{A_{\text {panel }}}\right)^{2}+1.0$ 
where;

$R$ is the reduction factor to account for the openings

$A_{\text {open }}$ is the area of the wall opening(s)

$A_{\text {panel }}$ is the total area of the masonry infill panel

The parameters; $w, d_{m}, h, h_{w}$ and $\theta$ are defined in Fig. 3.
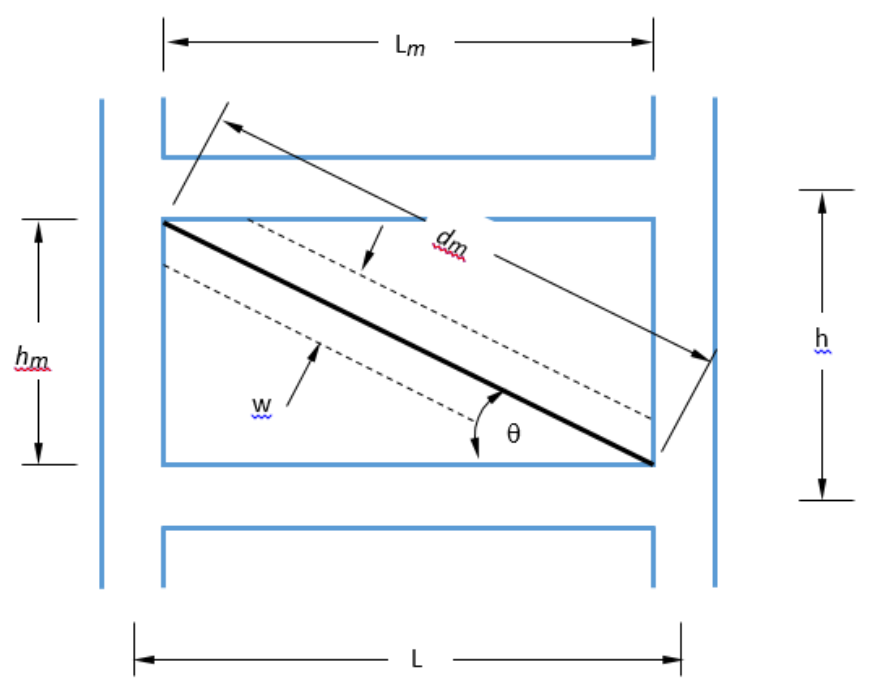

FIGURE 3 DIMENSIONS OF PARAMETERS

Finally the offset $\mathrm{z}$ in Fig. 2d can be determined is given in (6) as;

$$
z=\frac{\pi}{2 \lambda_{h}} h
$$

Although the expressions do not specifically indicate, it should be noted that;

- The width, $w$, must be evenly distributed between the two strut elements shown in Fig.2d,

- The thickness, $t$, of the strut should exclude the cavity thickness of the wall,

- The strut elements are compression members.

\section{Methodology}

\section{A. Experimental Test Structure}

Stavridis conducted dynamic experimental testing on a two bay three storey RC framed building with masonry infill panel which is shown in Fig. 4 [12]. The paper by Stavridis is sufficiently detailed by providing the necessary geometric and material properties as well as test results to develop a FE model. These properties were used to develop a FE model in ABAQUS. To avoid duplication of other research publications, the reader is referred to the paper by Stavridis for all geometric and material properties of the test structure.

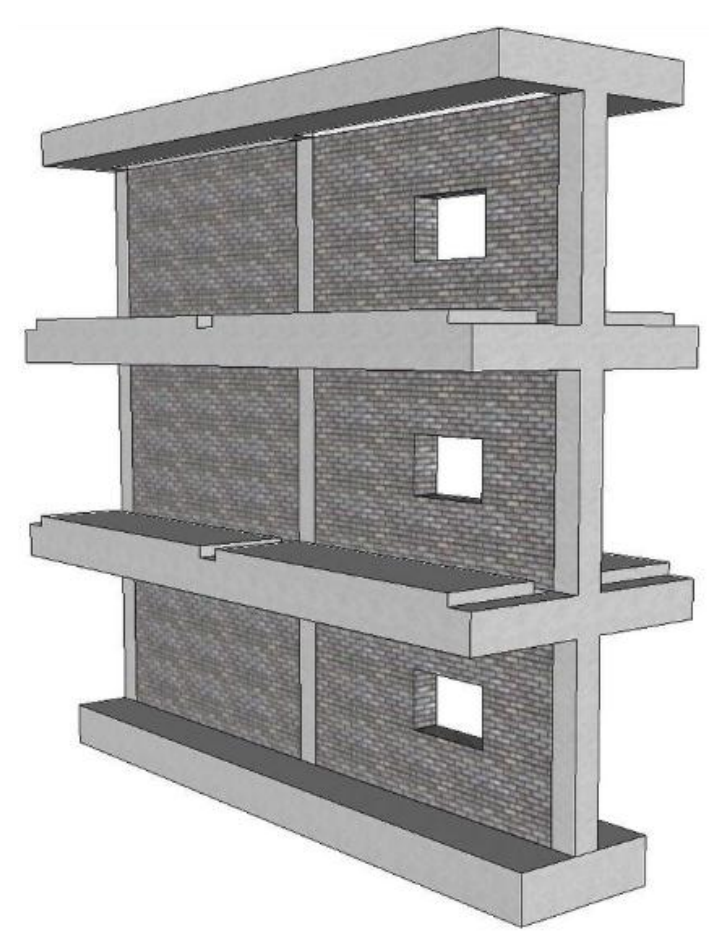

FIGURE 4 RC FRAMED STRUCTURE WITH MASONRY INFILL USED FOR FE CALIBRATION ( [12] )

Finally, complete content and organizational editing before formatting. Please take note of the following items when proofreading spelling and grammar:

\section{B. FE Calibration to the Experimental Test Structure}

The FE model was developed in ABAQUS v 6.10, a commercially available general purpose FE software. In order to develop a computationally efficient three dimensional FE model, it was imperative to avoid solid (brick) elements. It was therefore decided to model the beams and columns with three dimensional three node quadratic beam elements (B32). The slabs were modelled using eight node doubly curved thick shell elements using reduced integration with six degrees of freedom per node (S8R). To account for the stiffness of the masonry, the masonry panels were modelled as three dimensional three node quadratic truss elements (T3D3) using the concepts describe under "Modelling of the Masonry Infill". Material and geometric properties were assigned to the beam and shell elements using the detailed experimental test data provided by Starvidis. An assumption was made that the connections between columns and beams were rigidly connected (i.e. full moment transfer), while the connection of the slab to the beam was pinned (i.e. no moment transfer). It was also assumed that the base beam was rigidly connected to the ground. The connections between the equivalent struts and the columns were modelled using pin connections since the struts are modelled as compression members. These assumptions were made based on the anchorage of the reinforcement at the connections of the experimental test structure. The FE model of the test structure composed of beam and shell elements is shown in Fig. 5. 


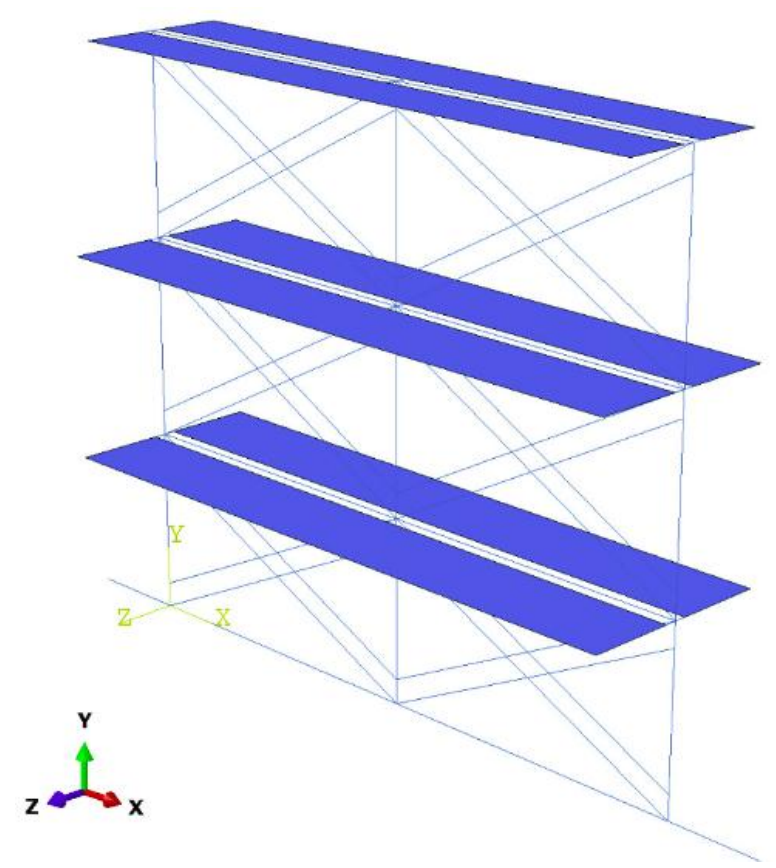

FIGURE 5 FE MODEL OF THE TEST STRUCTURE

The paper by Stavridis was detailed and supplied many of the geometric and material properties. The densities of the concrete and masonry was not supplied, however, the total weight of the structure was provided. The Concrete Society of the United Kingdom specifies that the densities of concrete range between 1800 to $2400 \mathrm{~kg} / \mathrm{m}^{3}$, while the density of unreinforced masonry can vary between 650 to $1500 \mathrm{~kg} / \mathrm{m}^{3}$ [13]. The density of the masonry was kept constant at $\quad 1000 \mathrm{~kg} / \mathrm{m}^{3}$ while the density of the concrete was varied to $2004 \mathrm{~kg} / \mathrm{m}^{3}$ to obtain the correct weight of the structure at $\quad 645 \mathrm{kN}$. After the weight of the structure was calibrated, it was necessary to calibrate the stiffness of the structure to obtain its correct frequency of $17.85 \mathrm{~Hz}$. The columns and beams of the structures are all composed of RC. As these elements are modelled as homogeneous materials, it was necessary to reduce the composite section elastic moduli to a single value $\bar{E}$. This was achieved by (7) as;

$$
\bar{E}=\frac{E_{C} A_{C}+E_{S} A_{S}}{A_{C}+A_{S}}
$$

where;

$E_{C}$ is the Young's Modulus of concrete

$A_{C}$ is the cross sectional area of concrete

$E_{S}$ is the Young's Modulus of steel

$A_{S}$ is the cross sectional area of steel

The Elastic Moduli of the RC sections ranged between 18.1 and $21.9 \mathrm{GPa}$ due to the different cross sections and reinforcement layout.

The properties of the masonry infill were determined using the procedure discussed in "Modelling of the Masonry Infill". The Elastic Modulus of the equivalent strut was obtained as $6.5 \mathrm{GPa}$ with an area of each strut without opening as $90808 \mathrm{~mm}^{2}$ and an area of each strut with opening as $79079 \mathrm{~mm}^{2}$, respectively. A dynamic implicit analysis of the structure yielded a frequency of $13.07 \mathrm{~Hz}$ when the properties of the RC sections and strut were used. The difference between the actual frequency and the FE model frequency was unacceptable. The RC elements stiffness was recalibrated using the American Concrete Institute guidelines is given in (8) as, [14];

$$
E_{C}=0.043 \rho_{C}^{1.5} f_{C}^{0.5}
$$

where;

$\rho_{C}$ is the density of concrete

$f_{C}$ is the compressive strength of concrete

Using this approach, the Elastic Moduli for the various RC members range from 25.9 to $29.6 \mathrm{GPa}$. Using the revised Elastic Moduli of the RC sections and the original properties of the strut yielded a revised frequency of 13.86 $\mathrm{Hz}$. This therefore shows that an increase in the RC stiffness made an insignificant difference to the structures frequency. It was therefore decided to adjust the Elastic Moduli of the masonry panels. Table II shows the effect that an increase in the Elastic Moduli of the equivalent strut has on the frequency of the structure.

TABLE II. Elastic MODUlus OF MASONRY VS FREQUENCY OF THE STRUUCTURE

\begin{tabular}{|c|c|}
\hline $\begin{array}{c}\text { Elastic Modulus of Masonry } \\
(\mathbf{G P a})\end{array}$ & $\begin{array}{c}\text { Frequency of the Structure } \\
(\mathbf{H z})\end{array}$ \\
\hline 6.25 & 13.86 \\
\hline 13 & 17.26 \\
\hline 14 & 17.26 \\
\hline 15 & 17.88 \\
\hline
\end{tabular}

A final elastic modulus of the masonry was thus chosen as $14.9 \mathrm{GPa}$ which resulted in the structure's frequency of $17.85 \mathrm{~Hz}$ which matches the experimental frequency. In addition, the element mesh size was also considered to ensure that it had an insignificant effect on the model's results and to ensure computational efficiency was also achieved.

The experimental model was also subjected to 1989 Loma Prieta earthquake measured at station Gilroy 3 for the North South direction. The same earthquake was applied to the base of the FE model for further validation. The acceleration response at roof was used for comparison purposes. The initial FE acceleration at roof height did not accurately match the experimental test data results. It was concluded that the discrepancy was as a result of the inherent damping in the experimental structure, which was not catered for in the original FE model. Damping in the FE model could either be applied using an automatic stabilization damping factor or applying Rayleigh damping to the structure. It was however decided to use the Rayleigh damping. After several simulations the Rayleigh damping factors were obtained as $\quad \alpha=0.3$ and $\beta=0.0020$. Without any other adjustments to the FE model the base shear forces were compared. The FE model yielded a maximum base shear force within $0.6 \%$ of the experimental 
results for the same lateral acceleration response. This proved that the FE model was correctly calibrated and could therefore be used for additional FE simulations. Since the test structure has similar properties to the actual model, it was decided to use the damping properties as well as the lesson learnt in the validation process. The reader is referred to Wesley, for a detailed description of the calibration process [15].

\section{Conclusions}

This paper shows that it is important to consider the stiffness of the unreinforced masonry infill panels as it has a significant effect on the overall structure's response, in terms of; total weight of the structure, base shear forces, natural frequency of the structure and possible over estimation of the columns stiffness if the effects of the masonry is ignored.

\section{Acknowledgment}

The financial assistance of the Department of Civil Engineering at Stellenbosch University, Stellenbosch University's Department of Research Development and the National Research Foundation (NRF) towards this research is hereby acknowledged. Opinions expressed and conclusions arrived at, are those of the authors and are not necessarily to be attributed to the NRF.

\section{References}

[1] T. Paulay and J. Priestley, Seismic Design of Reinforced Concrete and Masonry Buildings, Wiley-interscience publication, John Wiley \& Sons, 1992.

[2] J. Retief and P. Dunaiski, (2009), Background to SANS 10160: Basis of Structural Design and Actions for Building and Industrial Structures, SANS standard, SUN Press, 2009.

[3] A. B. Mehrabi, Performance of masonry-infilled R/C frames under inplane lateral loads, University of Colorado, Department of Civil, Environmental \& Architectural Engineering, 1994.

[4] W. Daknakhni, A. Hamid and M. Elgaaly, "Strength and stiffness prediction of masonry infill panels", Proceedings of 13th World Conference on Earthquake Engineering, pp. 1-6, 2004 .

[5] Polyakov, S., Masonry in framed buildings: An investigation into the strength and stiffness of masonry infilling. National Lending Library for Science and Technology, 1963.

[6] J. Donea, P. Jones and of the European Communities. Joint Research Centre. Ispra Establishment, C. (1991), Experimental and Numerical Methods in Earthquake Engineering, Eurocourses: Reliability \& Risk Analysis, Springer. 1991.

[7] F. Crisafulli, A. Carr and R. Park, "Analytical modelling of infilled frame structures: A general review", Bulletin of the New Zealand National Society for Earthquake Engineering, vol. 33, no. 1, pp. 3047, 2000.

[8] B. Stafford-Smith, "Lateral Stiffness of Infilled Frames", vol. 88. Proceedings of the American Society of Civil Engineering, Journal of Structural Division, 1962.

[9] R. Mainstone, "On the Stiffness and Strengths of Infilled Frames", vol. Supplement IV, Proceedings of the American Society of Civil Engineering, 1971.

[10] T. Liauw and K. Kwan, "Nonlinear behaviour of Non-Integral Infilled Frames", vol. 8. Computers and Structures, 1984

[11] Al-Chaar, L. Ghassan and A. Mehrabi, Constitutive models for nonlinear finite element analysis of masonry prisms and infill walls. No. ERDC/CERL-TR-08-19, ENGINEER RESEARCH AND DEVELOPMENT CENTER CHAMPAIGN IL CONSTRUCTION ENGINEERING RESEARCH LAB, 2008.

[12] A. Stavridis, I. Koutromanos and Shing, P.B, "Shake-table tests of a three-story reinforced concrete frame with masonry infill walls",
Earthquake Engineering and Structural Dynamics, vol. 41, no. 6, pp. 1089-1108, 2012.

[13] Concrete Society of the United Kingdom, 2013

[14] American Concrete Institute, Building Code Requirements for Structural Concrete (ACI 318-08) and Commentary. American Concrete Institute, Available at: http://books.google.co.za/books?id=c6yQszMV2-EC

[15] W. Jarvis, The effect of seismic activity on reinforced concrete frame structures with infill masonry panels, M.Eng. thesis, Stellenbosch University, 2014.

About Author (s)

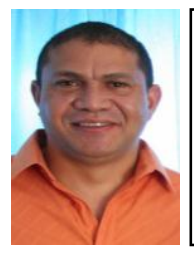

Structural engineers must incorporate the stiffness of the unreinforced infill masonry panels in their designs to achieve realistic structural behaviour 